\title{
Acute risk for hepatitis $E$ virus infection among HIV-1-positive pregnant women in central Africa
}

\author{
Mélanie Caron ${ }^{1}$, Julie Bouscaillou ${ }^{2}$ and Mirdad Kazanji ${ }^{1,2^{*}}$
}

\begin{abstract}
Background: Hepatitis E virus (HEV), an enterically transmitted pathogen, is highly endemic in several African countries. Pregnant women are at particularly high risk for acute or severe hepatitis E. In Gabon, a central African country, the prevalence of antibodies to HEV among pregnant women is $14.1 \%$. Recent studies have demonstrated unusual patterns of hepatitis $\mathrm{E}$ (chronic hepatitis, cirrhosis) among immunodeficient patients.

Findings: We investigated the prevalence of antibodies to HEV among pregnant women infected with HIV-1 or HTLV-1 in Gabon. Of 243 samples collected, 183 were positive for HIV-1 and 60 for HTLV-1; 16 women (6.6\%) had IgG antibodies to HEV. The seroprevalence was higher among HIV-1-infected women (7.1\%) than HTLV-1-infected women (5.0\%). Moreover, the HIV-1 viral load was significantly increased $(p \leq 0.02)$ among women with past-HEV exposure $(1.3 \mathrm{E}+05$ vs $5.7 \mathrm{E}+04$ copies per $\mathrm{ml}$ ), whereas no difference was found in HTLV-1 proviral load (9.0E+01 vs $1.1 \mathrm{E}+03$ copies per $\mathrm{ml})$.
\end{abstract}

Conclusions: These data provide evidence that HIV-1-infected women are at risk for acute or severe infection if they are exposed to HEV during pregnancy, with an increased viral load.

Keywords: HEV prevalence, HIV-1 and HTLV-1 infections, Pregnant women, Gabon, Central Africa

\section{Findings}

Hepatitis E virus (HEV) is an enterically transmitted pathogen that causes widescale epidemics of acute hepatitis in highly HEV-endemic areas such as Africa, Asia and the Middle East [1]. Sporadic cases are also observed in Europe, Japan, Russia and the USA, where HEV is spread mainly by zoonotic foodborne transmission [2]. Although perinatal and bloodborne transmission may occur, the main route of $\mathrm{HEV}$ transmission worldwide remains ingestion of fecal-contaminated water [3].

Many HEV outbreaks have been described in Africa, such as that recently observed in Uganda, with over 10 000 cases of acute hepatitis and 160 deaths [4]. The prevalence of antibodies to HEV varies widely in Africa, from $4.4 \%$ in the rural population of Ghana to $84.3 \%$ among pregnant women in Egypt [5,6]. In a previous study, we found a prevalence of $14.1 \%$ among pregnant women in Gabon [7].

\footnotetext{
* Correspondence: mirdad.kazanji@pasteur.fr

'Unité de Rétrovirologie, Centre International de Recherches Médicales, Franceville, BP 769, Gabon

${ }^{2}$ Institut Pasteur de Bangui, Réseau International des Instituts Pasteur, Bangui,

Central African Republic
}

(c) 2012 Caron et al.; licensee BioMed Central Ltd. This is an Open Access article distributed under the terms of the Creative Commons Attribution License (http://creativecommons.org/licenses/by/2.0), which permits unrestricted use, distribution, and reproduction in any medium, provided the original work is properly cited.

HEV is responsible for self-limiting or acute hepatitis, the severity ranging from benign to fulminant forms [8]. Hepatitis $E$ is associated with a mortality rate of $\leq 4 \%$, in particular among young adults, and up to $20 \%$ among pregnant women [9]. Obstetric complications due to HEV infection might be partly explained by hormonal changes and immune factors [10]. A study on maternal and fetal outcomes in India showed that pregnant women with acute hepatitis $\mathrm{E}$ had a 2.7 times higher relative risk for fulminant hepatic failure and a 6.0 times higher risk for mortality [11].

Persistent carriage of HEV has been described recently, with cases of chronic hepatitis and cirrhosis among organ-transplant recipients under immunosuppressive therapy [12-14]. In studies of acute hepatitis E among HIV-1-infected patients $[15,16]$, it has been suggested that hepatitis $\mathrm{E}$ can become chronic in people with severe immunodeficiency [17]. Long-term carriage of HEV might therefore warrant increased awareness and vigilance in cases of HIV-1 infection.

Previous studies conducted by our group among pregnant women in Gabon showed that the prevalence of HIV-1 infection is $6.3 \%$ and that of another human 
retrovirus, HTLV-1, is $2.1 \%$ [18,19]. The two viruses (HIV-1 and HTLV-1) have identical modes of transmission (sexual) and induce immunological disorders. As co-infections might occur in populations that are highly exposed to common risk factors and co-infection of a woman with a pre-existing infection with HIV-1 or HTLV-1 might increase the severity of disease, we investigated the prevalence of antibodies to HEV among HIV-1- and HTLV-1-infected pregnant women in Gabon. A cohort of 243 pregnant women was followed at the International Centre for Medical Research in Franceville, Gabon. Blood samples were collected anonymously, and only sociodemographic data were retained after informed consent. The study obtained ethical clearance from the Gabonese public health authorities (Ministry of Health) and from the Gabonese scientific and national ethical committees (Authorization no 093/MSP/SG/SGAQM).

After serological and confirmation assays for diagnosis of HIV-1 and HTLV-1/2, the HIV-1 viral load was determined with "Generic HIV Charge Viral (Biocentric, France)" and the HTLV-1 proviral load as previously described by Besson et al. [20]. IgG antibodies to HEV were measured with an ELISA (TMB) Kit (Genelabs Diagnostics, Singapore) according to the manufacturer's instructions. None of pregnant women in our study was co-infected with HIV-2, HTLV-2, HBV/HDV or HCV. Statistical analyses were conducted with STATA 11.0 software.

Of the 243 pregnant women, 183 were infected with HIV-1 and 60 with HTLV-1 (Table 1). The mean age of the study population was $28.2 \pm 6.5$ years (range, 14-43 years). The mean age of the HIV-1-infected women was $27.9 \pm 6.2$ years (range, $15-43$ years), and the median viral load was $6.1 \mathrm{E}+04$ copies per $\mathrm{ml}$ (first quartile, $1.5 \mathrm{E}+04$ copies per $\mathrm{ml}$; third quartile, $2.6 \mathrm{E}+05$ copies per $\mathrm{ml}$ ). The mean age of the HTLV-1-infected women was $29.1 \pm 7.1$ years (range, 16-42 years), and the median proviral load was $9.3 \mathrm{E}+02$ copies per $\mathrm{ml}$ (first quartile, 2.7E+02 copies per $\mathrm{ml}$; third quartile, $3.8 \mathrm{E}+03$ copies per $\mathrm{ml}$ ).

Sixteen of the 243 pregnant women (6.6\%) had IgG antibodies to HEV (Table 1). The seroprevalence did not depend significantly on viral status (HIV-1 positive or HTLV-1-positive) or age. HTLV-1-infected women with past exposure to HEV had lower proviral loads than those without past exposure. Nevertheless, the sample size and seroprevalence in this population were low, making it difficult to detect a significant difference. Conversely, the seroprevalence tended to increase with HIV1 viral load ( $p \leq 0.02$ with the Cuzick non-parametric test for trend [21]), when HIV-1 status was stratified into three groups: uninfected and HIV-1 positive, HIV-1 positive with viral load $\leq$ median and HIV-1 positive, HIV-1 positive with viral load > median and HIV-1 positive (Table 1, Figure 1). HIV-1-infected women with a high viral load were at higher risk for acute or severe hepatitis E.

Previously, we found HEV prevalences of $6.4 \%$ in rural and $13.5 \%$ in urban Gabonese pregnant women, which were significantly different $(p<0.05)$ [7]. In this study, we found that the risk for HEV infection of pregnant women infected with HIV-1 or HTLV-1 was similar to that of women living in rural areas. This finding corroborates our previous report of endemic HEV circulation in Gabon and indicates active autochthonous HEV transmission among women of reproductive age. While no effect of past HEV exposure was found on the prevalence of HTLV-1 infection, an increased prevalence of antibodies to HEV was associated with a high HIV-1 load.

It is possible that HIV-1 infection predisposes to HEV acquisition, as suggested in a study in the Russian Federation, which showed an association between a higher HEV prevalence and more advanced HIV-1 related disease [22]. Recently, persistent carriage of $\mathrm{HEV}$ has been observed among patients with HIV-1 infection. This might usually be

Table 1 Viral status by prevalence of antibodies to hepatitis E virus (HEV) among pregnant women in Gabon, central Africa

\begin{tabular}{|c|c|c|c|c|c|c|}
\hline Viral status & HEV status & No. (\%) & Mean age (years) (SD) & $p$ & Median viral load (copies/ml) [FQ-TQ] & $p$ \\
\hline \multirow[t]{3}{*}{ HIV-1+ } & $\mathrm{HEV}+$ & 13 & $26.3(4.5)$ & NS & $1.3 \mathrm{E}+05[5.1 \mathrm{E}+04-9.2 \mathrm{E}+05]$ & $\leq 0.02$ \\
\hline & HEV- & 170 & $28.0(6.3)$ & & $5.7 \mathrm{E}+04[1.5 \mathrm{E}+04-2.4 \mathrm{E}+05]$ & \\
\hline & Total & $13 / 183(7.1)$ & $27.9(6.2)$ & & $6.1 \mathrm{E}+04[1.5 \mathrm{E}+04-2.6 \mathrm{E}+05]$ & \\
\hline \multirow[t]{3}{*}{ HTLV-1+ } & $\mathrm{HEV}+$ & 3 & $33.7(5.4)$ & NS & $9.0 \mathrm{E}+01[6.0 \mathrm{E}+00-5.7 \mathrm{E}+02]$ & NS \\
\hline & HEV- & 57 & $28.8(7.1)$ & & $1.1 \mathrm{E}+03[2.8 \mathrm{E}+02-3.9 \mathrm{E}+03]$ & \\
\hline & Total & $3 / 60(5.0)$ & $29.1(7.1)$ & & $9.3 \mathrm{E}+02[2.7 \mathrm{E}+02-3.8 \mathrm{E}+03]$ & \\
\hline \multirow[t]{3}{*}{ Total } & $\mathrm{HEV}+$ & 16 & $27.8(5.5)$ & NS & - & - \\
\hline & $\mathrm{HEV}_{-}$ & 227 & $28.2(6.5)$ & & - & \\
\hline & Total & $16 / 243(6.6)$ & $28.2(6.5)$ & & - & \\
\hline
\end{tabular}

HEV+: IgG antibodies to HEV in serum; HIV-1, human immunodeficiency virus type 1; HTLV-1, human T-cell leukemia virus type 1; No., number of pregnant women; SD, standard deviation; [FQ-TQ], first quartile-third quartile; NS, not significant; -, not done.

Significance level $(p<0.05)$ calculated with Student $t$ test for age, Fisher exact test for viral status, and Wilcoxon-Mann-Whitney test for viral load, as the distribution was not normal. 


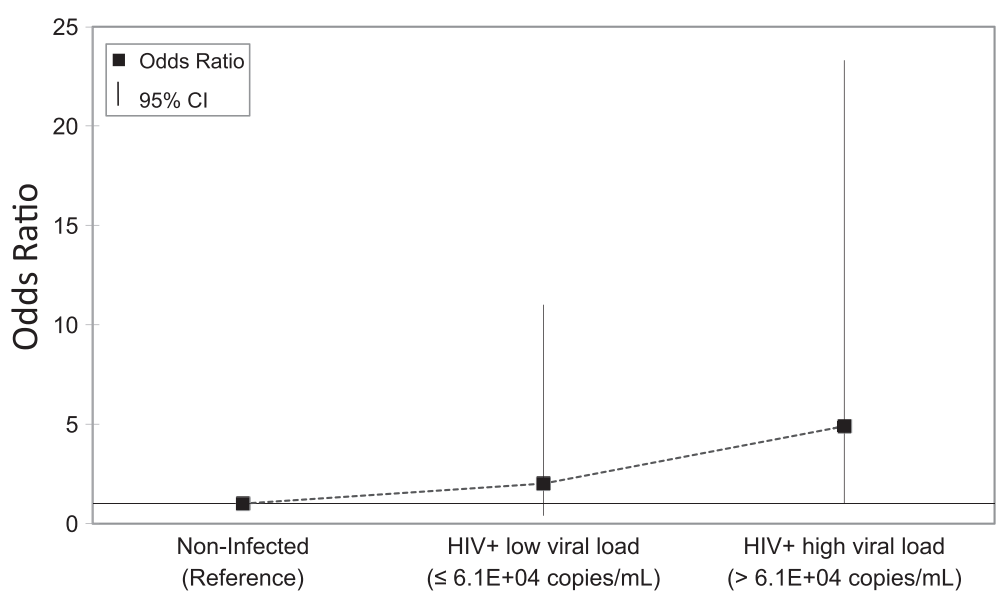

Viral status

Figure 1 Odds ratios for having IgG antibodies to hepatitis E virus (HEV) by human immunodeficiency virus (HIV-1) status and viral load.

overlooked because of common drug-induced liver injury among patients receiving antiretroviral therapy [23]. HEV infection could, however, represent a differential diagnosis of hepatitis in pregnancy [24]. As in our study, most HIV1 -infected pregnant women do not have HEV antibodies, placing them at increased risk for acute or severe hepatitis $E$ in an area endemic for both viruses.

HIV-1-infected pregnant women in Gabon appear to have a specific risk for HEV acquisition, with an increased viral load. No studies of hepatitis E have been conducted in the general population of Gabon, and the sources of infection remain unknown. In conclusion, HEV might be an important unrecognized cause of fatal hepatitis, particularly among HIV-1-positive pregnant women.

\section{Competing interests}

The authors declare that they have no competing interests.

\section{Authors' contributions}

MC carried out the serological and molecular studies, JB performed the statistical analysis. MC, JB and MK conceived and designed the study and were involved in drafting the manuscript. All the authors read and approved the final manuscript.

\section{Acknowledgments}

We thank Paul Ngari and Philippe Engandja for technical help. We are grateful for active collaboration with the National Programme against AIDS and the "Service de Coopération et d"Action Culturelle" of the French Embassy, Libreville, Gabon. The International Centre for Medical Research in Franceville is funded by the Gabonese Government, Total Gabon and the French Foreign Ministry.

Received: 4 April 2012 Accepted: 30 October 2012

Published: 31 October 2012

\section{References}

1. Mushahwar IK: Hepatitis E virus: molecular virology, clinical features, diagnosis, transmission, epidemiology, and prevention. J Med Virol 2008 , 80:646-658

2. Feagins AR, Opriessnig T, Guenette DK, Halbur PG, Meng XJ: Detection and characterization of infectious hepatitis $E$ virus from commercial pig livers sold in local grocery stores in the USA. J Gen Virol 2007, 88:912-917.

3. Colson P, Coze C, Gallian P, Henry M, De Micco P, Tamalet C: Transfusionassociated hepatitis E, France. Emerg Infect Dis 2007, 13:648-649.

4. Teshale EH, Howard CM, Grytdal SP, Handzel TR, Barry V, Kamili S, et al: Hepatitis E epidemic, Uganda. Emerg Infect Dis 2010, 16:126-129.

5. Martinson FE, Marfo VY, Degraaf J: Hepatitis E virus seroprevalence in children living in rural Ghana. West Afr J Med 1999, 18:76-79.

6. Stoszek SK, Abdel-Hamid M, Saleh DA, El Kafrawy S, Narooz S, Hawash Y, et al: High prevalence of hepatitis $\mathrm{E}$ antibodies in pregnant Egyptian women. Trans R Soc Trop Med Hyg 2006, 100:95-101.

7. Caron M, Kazanji M: Hepatitis E virus is highly prevalent among pregnant women in Gabon, central Africa, with different patterns between rural and urban areas. Virol I 2008, 5:158.

8. Emerson SU, Purcell RH: Hepatitis E virus. Rev Med Virol 2003, 13:145-154.

9. Purcell RH, Emerson SU: Hepatitis E: an emerging awareness of an old disease. J Hepatol 2008, 48:494-503.

10. Navaneethan U, Al Mohajer M, Shata MT: Hepatitis E and pregnancy: understanding the pathogenesis. Liver Int 2008, 28:1190-1199.

11. Patra S, Kumar A, Trivedi SS, Puri M, Sarin SK: Maternal and fetal outcomes in pregnant women with acute hepatitis E virus infection. Ann Intern Med 2007, 147:28-33.

12. Gerolami R, Moal V, Colson P: Chronic hepatitis E with cirrhosis in a kidney-transplant recipient. N Engl J Med 2008, 358:859-860.

13. Kamar N, Mansuy JM, Cointault O, Selves J, Abravanel F, Danjoux M, et al: Hepatitis E virus-related cirrhosis in kidney- and kidney-pancreastransplant recipients. Am J Transplant 2008, 8:1744-1748.

14. Haagsma EB, van den Berg AP, Porte RJ, Benne CA, Vennema H, Reimerink $\mathrm{JH}$, Koopmans MP: Chronic hepatitis E virus infection in liver transplant recipients. Liver Transp/ 2008, 14:547-553.

15. Colson P, Dhiver C, Gerolami R: Hepatitis E virus as a newly identified cause of acute viral hepatitis during human immunodeficiency virus infection. Clin Microbiol Infect 2008, 14:1176-1180.

16. Curry JA, Adams N, Crum-Cianflone NF: Acute hepatitis E virus infection in an HIV-infected person in the United States. Ann Intern Med 2009, 150:226-227.

17. Colson P, Kaba M, Moreau J, Brouqui P: Hepatitis E in an HIV-infected patient. J Clin Virol 2009, 45:269-271.

18. Caron M, Lekana-Douki SE, Makuwa M, Obiang-Ndong GP, Biba O, Nkoghe D, Kazanji M: Prevalence, genetic diversity and antiretroviral drugs resistance-associated mutations among untreated HIV-1-infected pregnant women in Gabon, central Africa. BMC Infect Dis 2012, 12:64.

19. Etenna SL, Caron M, Besson G, Makuwa M, Gessain A, Mahe A, Kazanji M: New insights into prevalence, genetic diversity, and proviral load of human T-cell leukemia virus types 1 and 2 in pregnant women in Gabon in equatorial central Africa. J Clin Microbiol 2008, 46:3607-3614. 
20. Besson G, Kazanji M: One-step, multiplex, real-time PCR assay with molecular beacon probes for simultaneous detection, differentiation, and quantification of human T-cell leukemia virus types 1, 2, and 3 . J Clin Microbiol 2009, 47:1129-1135.

21. Cuzick J: A Wilcoxon-type test for trend. Stat Med 1985, 4:87-90.

22. Balayan MS, Fedorova OE, Mikhailov MI, Rytick PG, Eremin VF, Danilova TI, et al: Antibody to hepatitis E virus in HIV-infected individuals and AIDS patients. J Viral Hepat 1997, 4:279-283.

23. Dalton HR, Bendall RP, Keane FE, Tedder RS, ljaz S: Persistent carriage of hepatitis E virus in patients with HIV infection. N Engl J Med 2009, 361:1025-1027.

24. Thoden J, Venhoff N, Miehle N, Klar M, Huzly D, Panther E, et al: Hepatitis E and jaundice in an HIV-positive pregnant woman. AIDS 2008, 22:909-910.

doi:10.1186/1743-422X-9-254

Cite this article as: Caron et al:: Acute risk for hepatitis $E$ virus infection among HIV-1-positive pregnant women in central Africa. Virology Journal 2012 9:254

\section{Submit your next manuscript to BioMed Central and take full advantage of:}

- Convenient online submission

- Thorough peer review

- No space constraints or color figure charges

- Immediate publication on acceptance

- Inclusion in PubMed, CAS, Scopus and Google Scholar

- Research which is freely available for redistribution 